\title{
Acute amnesia associated with damaged fiber tracts following anterior fornix infarction
}

Qing Yong Zhu, MD, PhD, Hong Can Zhu, MD, PhD, and Cheng Ru Song, MD

Neurology ${ }^{\circledR}$ 2018;90:706-707. doi:10.1212/WNL.0000000000005306
Correspondence

Dr. H.C. Zhu

hcan_zhu@126.com

Figure Brain MRI and diffusion tensor tracking of anterior fornix infarction
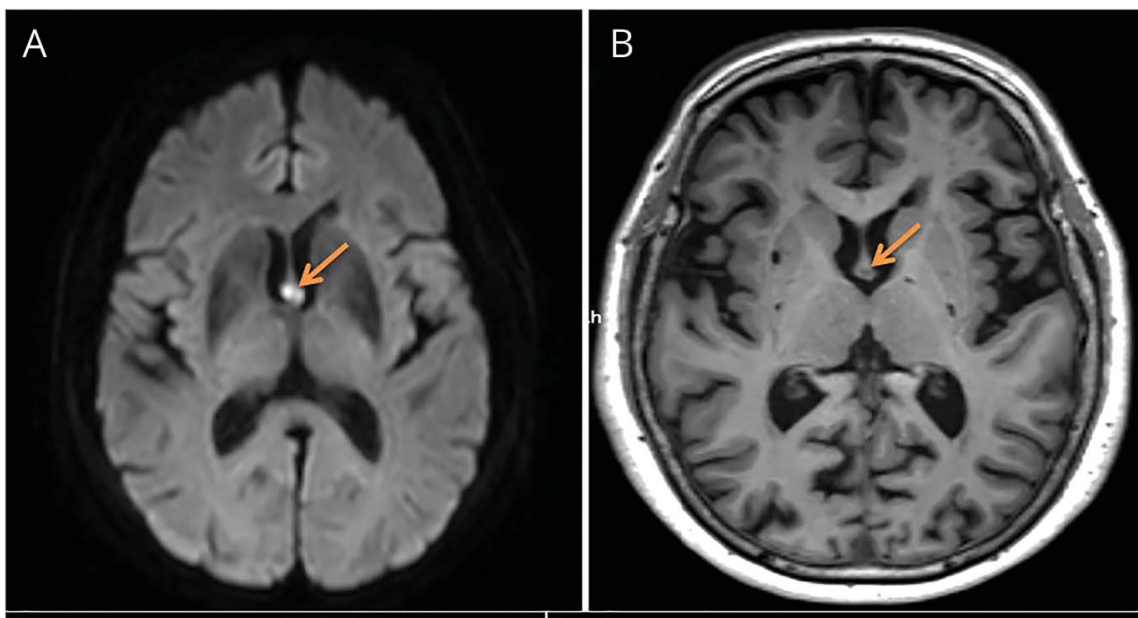

C

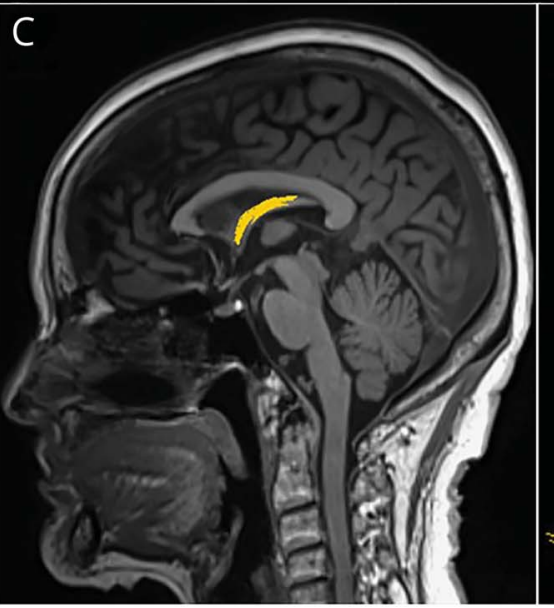

D

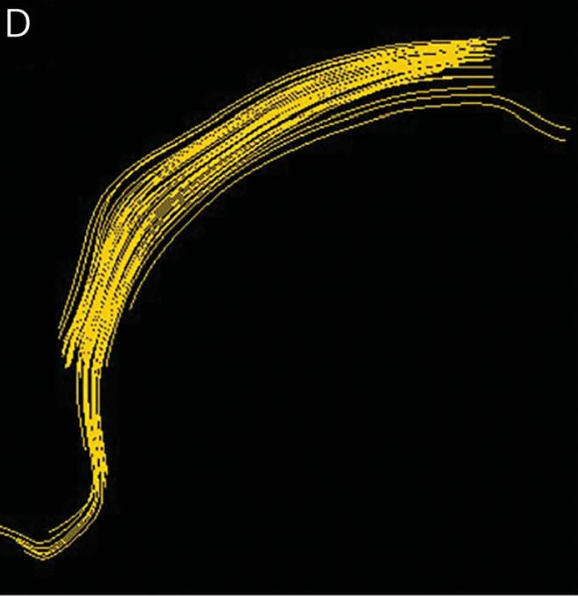

(A) Axial diffusion-weighted imaging reveals an acute infarction of the anterior fornix (arrow). (B) Repeat T1-weighted brain MRI at 17 days after onset shows hypointense lesions in the same region (arrow). (C, D) Diffusion tensor tracking demonstrates that few fibers were followed.

A 78-year-old woman developed sudden-onset confusion and memory impairment. Examination demonstrated both retrograde and anterograde amnesia. Mini-Mental State Examination score of 17 exhibited poor performance in delayed recall and orientation function. Brain diffusion-weighted imaging revealed an acute infarction of the anterior fornix. Repeat T1weighted images at 17 days after onset showed hypointense lesions in the same region. Meanwhile, diffusion tensor tracking was performed and demonstrated that few fibers were followed (figure), using Siemens (Munich, Germany) Syngo software with the measures of fractional anisotropy threshold 0.15 and angle 30 . The fornix constitutes a core element of the Papez circuit ${ }^{1,2}$ and acute amnesia was the result of damaged fiber tracts following anterior fornix infarction in this patient.

From the Departments of Neurology (Q.Y.Z., H.C.Z.) and Magnetic Resonance Imaging (C.R.S), The First Affiliated Hospital of Zhengzhou University, China. Go to Neurology.org/N for full disclosures. Funding information and disclosures deemed relevant by the authors, if any, are provided at the end of the article. 


\section{Author contributions}

Dr. Qing Yong Zhu: study concept and design, drafting the manuscript. Dr. Hong Can Zhu: revising the manuscript, interpretation of data. Dr. Cheng Ru Song: analysis and acquisition of radiologic data.

\section{Study funding}

No targeted funding reported.

\section{Disclosure}

The authors report no disclosures relevant to the manuscript. Go to Neurology.org/N for full disclosures.

\section{References}

1. Thomas AG, Koumellis P, Dineen RA. The fornix in health and disease: an imaging review. Radiographics 2011;31:1107-1121.

2. Hattingen E, Rathert J, Raabe A, Anjorin A, Lanfermann H, Weidauer S. Diffusion tensor tracking of fornix infarction. J Neurol Neurosurg Psychiatry 2007;78:655-656.

\section{AAN Wants to Help You with MIPS!}

MACRA and the Quality Payment Program and the 2018 Merit-based Incentive Payment System (MIPS) performance year began January 1. The AAN is committed to your success and has tools and resources to help you successfully meet your performance goals with minimal amount of effort. Take action today and visit AAN.com/view/QPP or email your questions tomacra@aan.com.

\section{Share Your Artistic Expressions in Neurology 'Visions'}

AAN members are urged to submit medically or scientifically related artistic images, such as photographs, photomicrographs, and paintings, to the "Visions" section of Neurology ${ }^{\circ}$. These images are creative in nature, rather than the medically instructive images published in the NeuroImages section. The image or series of up to six images may be black and white or color and must fit into one published journal page. Accompanying description should be 100 words or less; the title should be a maximum of 96 characters including spaces and punctuation.

Please access the Author Center at NPub.org/authors for full submission information.

\section{Seeking Concussion Abstracts by May 7}

Submit your concussion research for presentation in general poster sessions during the 2018 Sports Concussion Conference July 20 through 22 at the JW Marriott in Indianapolis, IN.

Visit AAN.com/view/ConcussionConference. 


\section{Neurology}

Acute amnesia associated with damaged fiber tracts following anterior fornix infarction Qing Yong Zhu, Hong Can Zhu and Cheng Ru Song

Neurology 2018;90;706-707

DOI 10.1212/WNL.0000000000005306

This information is current as of April 9, 2018

\section{Updated Information \&} Services

References

Subspecialty Collections

Permissions \& Licensing

Reprints including high resolution figures, can be found at: http://n.neurology.org/content/90/15/706.full

This article cites 2 articles, 1 of which you can access for free at: http://n.neurology.org/content/90/15/706.full\#ref-list-1

This article, along with others on similar topics, appears in the following collection(s):

\section{DWI}

http://n.neurology.org/cgi/collection/dwi

fMRI

http://n.neurology.org/cgi/collection/fmri

Infarction

http://n.neurology.org/cgi/collection/infarction

MRI

http://n.neurology.org/cgi/collection/mri

Information about reproducing this article in parts (figures,tables) or in its entirety can be found online at:

http://www.neurology.org/about/about_the_journal\#permissions

Information about ordering reprints can be found online:

http://n.neurology.org/subscribers/advertise

Neurology ${ }^{\circledR}$ is the official journal of the American Academy of Neurology. Published continuously since 1951, it is now a weekly with 48 issues per year. Copyright () 2018 American Academy of Neurology. All rights reserved. Print ISSN: 0028-3878. Online ISSN: 1526-632X.

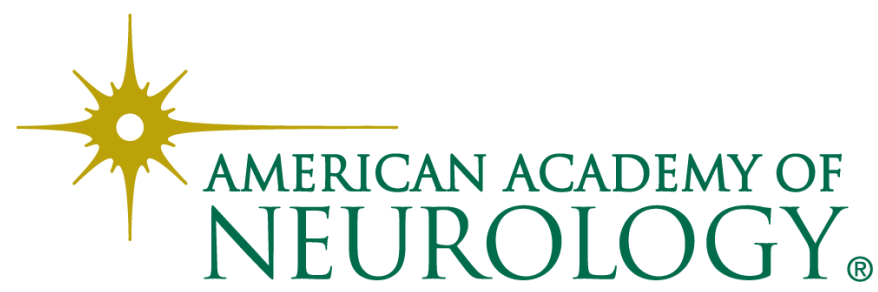

